\title{
Faktor Risiko terhadap Total Bakteri, Staphylococcus aureus, Koliform, dan Escherichia coli pada Susu Kambing
}

\author{
Risk Factor of Total Bacteria, Staphylococcus aureus, Coliform, and Escherichia coli in Goat Milk \\ Widodo Suwito ${ }^{1 *}$, Erna Winarti ${ }^{1}$, Felisitas Kristiyanti ${ }^{2}$, Ari Widyastuti ${ }^{1}$, A. Andriani ${ }^{3}$ \\ ${ }^{1}$ Balai Pengkajian Teknologi Pertanian Yogyakarta, Jl. Stadion Baru Maguwoharjo No. 22 Karang Sari, Wedomartani, \\ Ngemplak, Sleman, Yogyakarta 55584, Indonesia \\ ${ }^{2}$ Dinas Pertanian, Perikanan dan Kehutanan, Kabupaten Sleman, Jl. dr. Rajimin, Sucen, Triharjo, Sleman, Yogyakarta \\ 55514, Indonesia \\ ${ }^{3}$ Balai Besar Penelitian Veteriner Jl. R.E. Martadinata No. 30 Kotak Pos 151, Bogor 16124, Indonesia \\ * Email: widodo.suwito@yahoo.com
}

Submisi: 23 Maret 2017; Penerimaan: 16 Januari 2018

\begin{abstract}
ABSTRAK
Penelitian ini bertujuan untuk menentukan faktor risiko yang mempengaruhi total bakteri, Staphylococcus aureus ( $S$. Aureus), koliform, dan Escherichia coli (E. coll) pada susu kambing dari Kabupaten Sleman agar memenuhi persyaratan SNI No 01-6366-2000. Sebanyak 16 susu kambing dari Kabupaten Sleman digunakan dalam penelitian ini. Susu kambing diperiksa terhadap total bakteri, S. aureus, koliform, dengan hitungan cawan sedangkan $E$. coli berdasarkan reaksi biokimia. Manajemen pemerahan dari masing-masing peternakan ditulis dalam lembar kuesioner. Analisis bivariate chi square $\left(x^{2}\right)$, odds ratio (OR), dan relative risk (RR) digunakan untuk menentukan faktor risiko yang mempengaruhi total bakteri, $S$. aureus, koliform, dan E. coli pada susu kambing. Faktor risiko yang mempengaruhi total bakteri, $S$. aureus, koliform, dan E. coli dalam susu kambing adalah kebersihan kandang, tempat penampung susu, pengetahuan personal hygiene pemerah susu, mencuci ambing sebelum diperah, waktu dan banyaknya pemerahan.
\end{abstract}

Kata kunci: Bakteri; susu kambing; faktor risiko

\section{ABSTRACT}

The objective of this research is to determine the risk factors that affect the total bacteria, S. aureus, coliform, and $E$. coli in goat milk_against SNI No 01-6366-2000 requirements. A total of 16 samples of goat milk from Sleman district were analyzed for total bacteria, S. aureus, coliform using dilution plate count, whereas $E$. coli count was based on biochemical reaction. Management of each dairy goat farm was recorded using questionnaires. The risk factors of total bacteria, $S$. aureuS, coliform, and $E$. coli in goat milk were determined based on chi square $\left(X^{2}\right)$ bivariate analysis, odds ratio (OR), and relative risk (RR). The risk factors that affected total bacteria, $S$. aureus, coliform, and E. coli in goat milk are cleanliness of stall, milk containers, personal knowledge of dairy hygiene, washing of the udder before milking, the time and the amount of milking.

Keywords: Bacteria; goat milk; risk factor

\section{PENDAHULUAN}

Saat ini harga susu kambing lebih mahal dibandingkan dengan susu sapi. Salah satu penyebabnya adalah permintaan yang banyak sedangkan produksinya masih kurang. Kabupaten Sleman merupakan daerah penghasil susu kambing terbesar di Daerah Istimewa Yogyakarta dengan produksi 4593 L/tahun sedangkan produksi olahan susu kambing mencapai 6 kuintal per hari (SIDa,
2013). Sementara itu, produksi susu kambing di Kabupaten Sleman 4593 L/tahun lebih tinggi dibandingkan Kabupaten Bogor 2124 L/tahun dan Malang 3147 L/tahun (Statistik Peternakan dan Kesehatan Hewan, 2013).

Susu kambing juga dapat digunakan untuk menjaga kesehatan dan baik diberikan pada anak muda sampai orang tua (Ribeiro, 2010). Kelebihan susu kambing antara lain mempunyai kandungan protein yang tinggi 
yaitu 3,6\% sedangkan susu sapi 3,2\% dan sebagai sumber mineral, kalsium, serta fosfor yang baik untuk pertumbuhan bayi (Albenzio dan Santilo, 2011). Kelebihan susu kambing lainnya yaitu mempunyai butir lemak yang lebih kecil 18,92\%, sedangkan susu sapi proporsi asam lemak rantai pendek dalam jumlah yang banyak sekitar 30,80\% sehingga susu kambing mudah dicerna (Ceballos dkk., 2009). Oleh sebab susu kambing mudah dicerna, maka susu kambing dapat di berikan pada orang yang alergi susu sapi (Agamy, 2007). Susu kambing dapat juga dikonsumsi sebagai penganti susu sapi karena tidak bersifat alergen dan memiliki kecernaan yang tinggi sampai 98\% (Park dkk., 2007).

Susu kambing bersifat mudah rusak karena memiliki kadar protein tinggi. Protein dapat digunakan sebagai media pertumbuhan bakteri. Saat ini, salah satu kendala yang dihadapi peternak kambing peranakan Ettawa (PE) di Kabupaten Sleman adalah belum diketahui cara mengatasi kontaminasi bakteri dalam susu kambing. Kontaminasi bakteri dalam susu menyebabkan kualitasnya menjadi rendah dan susu olahan seperti pasteurisasi ditolak oleh konsumen karena jumlah bakteri mencapai >104 CFU/mL (Barbano dkk., 2006).

Sampai saat ini Standar Nasional Indonesia (SNI) tentang susu kambing belum tersedia, sehingga persyaratannya mengacu pada SNI No 01-6366-2000. Berdasarkan SNI No 01-6366-2000, persyaratan susu segar mempunyai total bakteri $1 \times 10^{6} \mathrm{CFU} / \mathrm{mL}$, S. aureus $1 \times 10^{2} \mathrm{CFU} / \mathrm{mL}$, koliform $2 \times 10^{1} \mathrm{CFU} / \mathrm{mL}$, Salmonella $s p$, dan $E$. coli negatif (BSN, 2000). Supaya dapat memenuhi persyaratan SNI tersebut, maka susu kambing perlu diketahui faktor-faktor risiko yang mempengaruhi total bakteri, $S$. aureus, koliform, dan E. coli. Sementara itu, penelitian tentang faktor-faktor risiko yang mempengaruhi total bakteri, $S$. aureus, koliform, dan $E$. coli dalam susu kambing belum pernah dilakukan. Oleh sebab itu, tujuan dari penelitian ini adalah untuk menentukan faktor risiko yang mempengaruhi total bakteri, S. aureus, koliform, dan E. coli dalam susu kambing dari Kabupaten Sleman supaya memenuhi persyaratan SNI No 01-6366-2000.

\section{METODE PENELITIAN}

\section{Bahan}

Penelitian ini menggunakan 16 sampel susu kambing yang diambil dari tempat penampung susu pada 16 peternakan kambing PE di Kabupaten Sleman.

\section{Koleksi Sampel}

Koleksi sampel dilakukan sekali dengan mengambil susu kambing pemerahan pagi hari dari tempat penampung susu pada masing-masing peternakan sebanyak $10 \mathrm{~mL}$. Selanjutnya sampel ditampung dalam botol plastik dan segera dimasukan ice box untuk dibawa ke laboratorium dan diproses lebih lanjut.

\section{Tempat Penelitian}

Pemeriksaan total bakteri, S. aureus, koliform, dan $E$. coli dalam susu kambing dilakukan di Laboratorium Kesehatan Masyarakat Veteriner, Fakultas Kedokteran Hewan, Universitas Gadjah Mada.

\section{Faktor Risiko}

Faktor risiko dikumpulkan saat wawancara dengan peternak dan pengamatan langsung saat pemerahan menggunakan kuesioner. Pertanyaan yang terdapat dalam lembar kuesioner antara lain: kebersihan kandang, tempat penampung susu, waktu pemerahan, banyaknya pemerahan, pemerah susu, mencuci ambing, dipping puting, dan mencuci tangan.

\section{Total Bakteri}

Penghitungan total bakteri dengan hitungan cawan mengacu pada (BSN, 2008). Susu kambing diambil 1 $\mathrm{mL}$, kemudian diencerkan dengan buffer peptone water (BPW) (Oxoid Ltd., Basingstoke, United Kingdom) sampai pengenceran $10^{-6}$. Selanjutnya masing-masing pengenceran diambil $1 \mathrm{~mL}$ dan dimasukkan ke cawan petri steril, kemudian dituangkan plate count agar (PCA) (Oxoid Ltd., Basingstoke, United Kingdom) dan dibiarkan sampai membeku. Setelah agar membeku, cawan petri diinkubasikan pada suhu $37{ }^{\circ} \mathrm{C}$. Jumlah koloni dihitung setelah 24-48 jam inkubasi.

\section{Jumlah S. Aureus}

Penghitungan jumlah $S$. aureus mengacu pada (BSN, 2008) dengan modifikasi. Modifikasi yang dilakukan yaitu media baired-parker agar (BPA) diganti vogel johson agar (VJA). Selain itu, modifikasi juga dilakukan dengan mengencerkan sampel sampai $10^{-6}$ dengan BPW (Oxoid Ltd., Basingstoke, United Kingdom). Selanjutnya masing-masing pengenceran diambil $1 \mathrm{~mL}$ dimasukkan cawan petri steril, kemudian dituang VJA (Oxoid Ltd., Basingstoke, United Kingdom) yang sebelumnya ditambah potassium tellurite $1 \%$. Setelah agar membeku, cawan petri diinkubasikan pada suhu $37^{\circ} \mathrm{C}$ selama 24-48 jam. Koloni yang dihitung yang berbentuk bulat, licin, berwarna abu-abu sampai hitam pekat yang dikelilingi oleh zona jernih yang jelas.

\section{Jumlah Koliform}

Jumlah koliform dihitung dengan mengacu pada (BSN, 2008) dengan modifikasi. Modifikasi yang dilakukan yaitu mengencerkan sampel sampai $10^{-6}$ dengan BPW (Oxoid Ltd., Basingstoke, United Kingdom). Selanjutnya masing-masing enceran diambil $1 \mathrm{~mL}$ dimasukkan cawan petri steril, kemudian dituang violet red bile agar (VRBA) (Oxoid Ltd., Basingstoke, United Kingdom). Setelah homogen dan membeku, dituang kembali VRBA di permukaan agar (overlay) dan setelah membeku diinkubasikan pada suhu $37^{\circ} \mathrm{C}$ selama 24-48 jam. Koloni yang dihitung adalah koloni yang berwarna merah keunguan dan dikelilingi oleh zona merah. 


\section{Isolasi dan identifikasi E. Coli}

Isolasi dan identifikasi E. coli mengacu pada (BSN, 2008) dengan modifikasi. Modifikasi yang dilakukan yaitu jumlah sampel dari $50 \mathrm{~mL}$ diganti $5 \mathrm{~mL}$. Selain itu, modifikasi juga dilakukan dengan menggunakan media Mac conkey agar (MCA) (Oxoid Ltd., Basingstoke, Inggris). Sebanyak $5 \mathrm{~mL}$ susu kambing ditambahkan dalam $25 \mathrm{~mL}$ tryptic soy broth (TSB) (Oxoid Ltd., Basingstoke, Inggris) kemudian diinkubasikan pada suhu $37{ }^{\circ} \mathrm{C}$ selama 24 jam. Selanjutnya subkultur pada Mac conkey agar (MCA) (Oxoid Ltd., Basingstoke, Inggris) dan eosin methylene blue agar (EMBA) (Oxoid Ltd., Basingstoke, Inggris) diinkubasikan pada suhu $37{ }^{\circ} \mathrm{C}$ selama 24 jam. Koloni pink, bulat, cekung pada MCA, dan metalik pada EMBA dilakukan pewarnaan Gram dan uji biokimiawi E. coli (Barrow dan Feltham, 1993).

\section{Analisis Data}

Total bakteri, S. aureus, koliform, dan E. colipada susu kambing dari Kabupaten Sleman dianalisis secara deskriptif, sedangkan faktor risiko dengan analisis bivariate chi square $\left(x^{2}\right)$, odds ratio $(\mathrm{OR})$, dan relative risk (RR) (Thrusfield, 1995).

\section{HASIL DAN PEMBAHASAN}

\section{Faktor Risiko Total Bakteri}

Hasil pemeriksaan kandungan total bakteri, S. aureus, koliform, dan E. coli disajikan dalam Tabel 1. Jumlah sampel susu kambing yang memenuhi memenuhi persyaratan SNI No 01-6366-2000 sebanyak 94\%, sedangkan lainnya mengandung bakteri yang melebihi persyaratan. Susu kambing dengan jumlah bakteri yang melebihi persyaratan SNI No 01-6366-2000 berasal dari peternakan L. Susu kambing dengan total bakteri melebihi persyaratan SNI No 01-6366-2000 dapat disebabkan oleh personal hygiene yang kurang dalam pemahaman sanitasi seperti pemerah susu tidak mencuci tangan sebelum melakukan pemerahan. Susu kambing dari peternakan $L$ diambil dari tempat penampung susu yang berupa ember plastik dan juga digunakan untuk keperluan ternak lainnya, sehingga risiko kontaminasi bakteri lebih besar. Hal tersebut juga didukung bahwa pemerah pada peternakan L tidak mencuci tangan sebelum pemerahan. Pemerah yang tidak mencuci tangan sebelum pemerahan di Kabupaten Sleman terdapat pada 10 peternakan yaitu sebesar $62 \%$, sedangkan yang mencuci tangan hanya 6 peternakan atau 38\% (Tabel 2). Taufik dkk. (2011) melaporkan bahwa susu kambing dari Bogor yang diambil langsung dari puting mempunyai risiko kontaminasi bakteri lebih sedikit sehingga mempunyai total bakteri $3,74 \times 10^{3} \mathrm{CFU} / \mathrm{mL}$ dan memenuhi persyaratan SNI No 01-6366-2000. Sementara itu di Australia susu kambing yang belum di pasteurisasi atau masih mentah memenuhi standar dan layak dikonsumsi apabila total bakteri 3,8 $810^{2} \mathrm{CFU} / \mathrm{mL}$ (Eglezos dkk., 2008).
Tabel 1. Pemeriksaan total bakteri, S. aureus, koliform, dan $E$. coli pada susu kambing dari Kabupaten Sleman

\begin{tabular}{|c|c|c|c|c|}
\hline \multirow[b]{2}{*}{ Peternakan } & \multicolumn{3}{|c|}{ Jumlah Koloni (CFU/mL) } & \multirow{2}{*}{$\begin{array}{l}\text { Isolasi } \\
\text { E. coli }\end{array}$} \\
\hline & $\begin{array}{c}\text { Total } \\
\text { Bakteri }\end{array}$ & S. aureus & Koliform & \\
\hline$A$ & $1 \times 10^{3}$ & - & - & - \\
\hline B & $5 \times 10^{3}$ & - & 10 & - \\
\hline $\mathrm{C}$ & $2 \times 10^{5}$ & $200 *$ & - & - \\
\hline D & $6 \times 10^{3}$ & - & 10 & - \\
\hline $\mathrm{E}$ & $2 \times 10^{4}$ & - & 10 & - \\
\hline$E$ & $8 \times 10^{5}$ & - & - & $+^{*}$ \\
\hline $\mathrm{G}$ & $6 \times 10^{3}$ & - & 10 & - \\
\hline $\mathrm{H}$ & $1 \times 10^{4}$ & - & 10 & - \\
\hline I & $4 \times 10^{4}$ & 10 & $300 *$ & - \\
\hline 了 & $3 \times 10^{4}$ & - & - & $+^{*}$ \\
\hline $\mathrm{K}$ & $2 \times 10^{3}$ & 20 & 10 & - \\
\hline $\mathrm{L}$ & $4 \times 10^{6 *}$ & $300 *$ & $60 *$ & $+^{*}$ \\
\hline$M$ & $8 \times 10^{3}$ & 10 & 10 & - \\
\hline $\mathrm{N}$ & $9 \times 10^{2}$ & - & - & - \\
\hline 0 & $5 \times 10^{4}$ & 10 & 10 & - \\
\hline$P$ & $3 \times 10^{5}$ & - & 10 & - \\
\hline $\begin{array}{l}\text { Memenuhi } \\
\text { SNI }\end{array}$ & $94 \%$ & $97 \%$ & $87 \%$ & $81 \%$ \\
\hline
\end{tabular}

Peternakan kambing di Kabupaten Sleman dengan kandang termasuk kategori bersih $81 \%$, sedangkan yang kotor $19 \%$ disajikan dalam Tabel 2. Kebersihan kandang dapat dilihat pada Tabel 3. Kandang yang bersih berkorelasi terhadap total bakteri dengan nilai $X^{2}=0,53 ; \mathrm{OR}=3$; dan $\mathrm{RR}=1,8$. Nilai $\mathrm{OR}$ kurang dari 1 menunjukkan efek negatif, OR sama dengan nol 0 menunjukkan tidak ada efek, dan nilai OR lebih dari 1 menunjukkan korelasi yang kuat (Thrusfield, 1995). Kebersihan kandang memiliki kekuatan 3 kali berpengaruh terhadap total bakteri dalam susu kambing, sehingga kebersihan kandang termasuk faktor risiko yang penting. Kandang yang bersih dapat mengurangi kejadian penyakit. Selain itu, kandang yang bersih dapat mengurangi kontaminasi bakteri dalam susu kambing. Oleh sebab itu menjaga kandang agar tetap bersih penting untuk mengurangi risiko susu kambing terkontaminasi bakteri.

Peternakan kambing di Kabupaten Sleman yang pemerahannya dilakukan oleh orang yang sama $62 \%$, sedangkan yang berganti-ganti orang sebanyak $38 \%$ (Tabel 2). Pemerahan pada masing-masing peternakan dapat dilakukan oleh orang yang sama atau ganti-ganti. Pemerahan yang dilakukan oleh orang yang sama atau ganti-ganti orang pada prinsipnya tidak berpengaruh terhadap total bakteri dalam susu asalkan pemahaman personal hygiene dan sanitasi sudah baik.

Pemerahan yang dilakukan orang yang sama atau ganti-ganti tidak termasuk dalam faktor risiko dengan nilai $\left(x^{2}=0,04 ; \mathrm{OR}=0,75 ; \mathrm{RR}=0,9\right)$ dan disajikan dalam Tabel 3. Sementara itu Suwito dkk. (2014) menyatakan bahwa kambing yang diperah oleh orang yang gantiganti menyebabkan stres dan trauma pada puting akibatnya susu yang dikeluarkan tidak lancar dan terjadi sakit mastitis. 
Tabel 2. Manajemen pemerahan pada peternakan kambing di Kabupaten Sleman

\begin{tabular}{|c|c|c|}
\hline \multirow[t]{2}{*}{ Variabel } & \multicolumn{2}{|c|}{$\begin{array}{c}\text { Total peternakan } \\
(\mathrm{n}=16)\end{array}$} \\
\hline & $\mathrm{n}$ & $(\%)$ \\
\hline \multicolumn{3}{|l|}{ Kebersihan kandang } \\
\hline Bersih & 13 & 81 \\
\hline Kotor & 3 & 19 \\
\hline \multicolumn{3}{|l|}{ Kondisi tempat penampung susu } \\
\hline Bersih & 7 & 44 \\
\hline Kotor & 9 & 56 \\
\hline \multicolumn{3}{|l|}{ Waktu pemerahan } \\
\hline Pagi & 9 & 56 \\
\hline Sore & 3 & 18 \\
\hline Pagi dan sore & 4 & 25 \\
\hline \multicolumn{3}{|l|}{ Banyaknya pemerahan } \\
\hline 1 kali & 13 & 81 \\
\hline 2 kali & 3 & 18 \\
\hline \multicolumn{3}{|l|}{ Pemerah susu } \\
\hline Orang yang sama & 10 & 62 \\
\hline Orang yang berbeda & 6 & 38 \\
\hline \multicolumn{3}{|l|}{$\begin{array}{l}\text { Mencuci tangan sebelum } \\
\text { pemerahan }\end{array}$} \\
\hline Ya & 6 & 38 \\
\hline Tidak & 10 & 62 \\
\hline \multicolumn{3}{|l|}{ Mencuci ambing sebelum diperah } \\
\hline Ya & 4 & 25 \\
\hline Tidak & 12 & 75 \\
\hline Mencuci tangan dengan air biasa & 2 & 50 \\
\hline Mencuci tangan dengan air hangat & 1 & 25 \\
\hline Mencuci tangan dengan desinfektan & 1 & 25 \\
\hline \multicolumn{3}{|l|}{ Dipping puting } \\
\hline Ya & 2 & 13 \\
\hline Tidak & 14 & 87 \\
\hline Dipping puting dengan desinfektan & 1 & 50 \\
\hline Dipping puting dengan air hangat & 1 & 50 \\
\hline
\end{tabular}

Tabel 3. Analisis faktor risiko total bakteri dalam susu kambing dari Kabupaten Sleman

\begin{tabular}{lccc}
\hline Variabel & $\left(x^{2}\right)$ & $\begin{array}{c}\text { Odds } \\
\text { Ratio } \\
(\mathrm{OR})\end{array}$ & $\begin{array}{c}\text { Relative } \\
\text { Risk(RR) }\end{array}$ \\
\hline Kebersihan kandang & 0,53 & $3^{*}$ & $1,8^{*}$ \\
Pemerah susu & 0,04 & 0,75 & 0,9 \\
Tempat penampungan susu & 0,53 & $1,5^{*}$ & $1,8^{*}$ \\
Waktu pemerahan & 2 & $3,2^{*}$ & $3,2^{*}$ \\
Banyaknya pemerahan & 2 & $3,2^{*}$ & $3,2^{*}$ \\
\hline
\end{tabular}

Keterangan: ${ }^{*}$ assosiasi kuat terhadap total bakteri
Susu kambing dari Kabupaten Sleman ditempatkan dalam penampung susu seperti milk can, botol plastik, atau jerigen. Tempat penampung susu yang termasuk bersih atau $44 \%$, sedangkan kotor ada $56 \%$ disajikan dalam Tabel 2. Tempat penampung susu berkorelasi dengan total bakteri (Tabel 3). Tempat penampung susu memiliki 1,5 kali lebih besar pengaruhnya terhadap total bakteri, sehingga tempat penampung susu termasuk faktor risiko. Tempat penampung susu dapat sebagai titik awal terjadinya kontaminasi bakteri. Hal tersebut terjadi saat tempat penampung susu dalam keadaan kotor seperti banyak lalat, semut, atau binatang lainnya. Oleh sebab itu, menjaga agar tempat penampung susu selalu bersih termasuk salah satu cara mengurangi kontaminasi bakteri pada susu kambing.

Frekuensi pemerahan kambing di Kabupaten Sleman pada masing-masing peternakan berbeda-beda. Sebanyak $81 \%$ peternak melakukan pemerahan sehari sekali sedangkan lainnya sehari dua kali. Terkait waktu pemerahan, sebanyak $56 \%$ peternak melakukannya pada pagi hari, $19 \%$ pada sore hari dan lainnya pada pagi dan sore hari. Frekuensi pemerahan dan waktu pemerahan berkorelasi dengan total bakteri dengan nilai $x^{2}=2 ; \mathrm{OR}=3,2$ dan $\mathrm{RR}=3,2$. Frekuensi pemerahan dan waktu pemerahan memiliki pengaruh 3,2 kali lebih besar terhadap total bakteri dalam susu kambing, sehingga frekuensi pemerahan, dan waktu pemerahan termasuk faktor risiko total bakteri dalam susu kambing. Kambing yang diperah 2 kali dalam sehari dapat menyebabkan otot spinter dari putting menjadi kendor dan bakteri akan mudah masuk ambing (Marogna dkk., 2012).

\section{Faktor Risiko Jumlah S. aureus}

Jumlah $S$. aureus dalam susu kambing dari 16 peternakan di Kabupaten Sleman yang memenuhi persyaratan SNI No 01-6366-2000 87\%, sedangkan sisanya melebihi persyaratan yang ditetapkan (Tabel 1). Jumlah S. aureus dalam susu kambing di Kabupaten Sleman yang melebihi persyaratan SNI No 01-63662000 dijumpai pada peternakan $\mathrm{C}$ dan $\mathrm{L}$.

Salah satu kemungkinan faktor penyebabnya adalah tidak dilakukannya pencucian ambing sebelum pemerahan. Sementara itu, peternakan kambing yang mencuci ambing sebelum diperah sebanyak 25\%, sedangkan yang tidak sebanyak $75 \%$ (Tabel 2). Permukaan kulit ambing dapat menjadi sumber $S$. aureus yang dapat mengkontaminasi susu. Oleh sebab itu, mencuci ambing sebelum diperah dapat mengurangi $S$. aureus. Permukaan kulit manusia maupun hewan terdapat $S$. aureus yang menghasilkan toksin tahan suhu $110{ }^{\circ} \mathrm{C}$ selama 30 menit dan menyebabkan diare pada manusia. Toksin S. aureus terbentuk apabila jumlahnya lebih dari $10^{6} \mathrm{CFU} / \mathrm{mL}$ dengan konsentrasi $1 \mu \mathrm{g}$ dapat menimbulkan gejala mual, muntah, dan kepala pusing (Alarcon dkk., 2006). Pemerah susu berkorelasi dengan jumlah S. aureus dalam susu kambing (Tabel 4). 
Tabel 4. Analisis faktor risiko jumlah $S$, aureus dalam susu kambing dari Kabupaten Sleman

\begin{tabular}{lccc}
\hline Variabel & $\left(x^{2}\right)$ & $\begin{array}{c}\text { Odds } \\
\text { ratio }(\mathrm{OR})\end{array}$ & $\begin{array}{c}\text { Relative } \\
\text { risk (RR) }\end{array}$ \\
\hline Kebersihan kandang & 0,53 & $3^{*}$ & $1,5^{*}$ \\
Pemerah susu & 2 & $3,2^{*}$ & $3,2^{*}$ \\
Tempat penampung susu & 0,53 & $3^{*}$ & $1,5^{*}$ \\
\hline \multicolumn{2}{l}{ Keterangan: ${ }^{*}$ assosiasi kuat terhadap S. aureus }
\end{tabular}

Pemerah susu memiliki pengaruh 3,2 kali lebih besar terhadap jumlah $S$. aureus dalam susu kambing. Oleh sebab itu pemerah susu termasuk faktor risiko jumlah $S$. aureus dalam susu kambing. Tangan pemerah merupakan sumber $S$. aureus yang dapat mengkontaminasi susu kambing, sehingga sebaiknya mencuci tangan dahulu sebelum melakukan pemerahan.

Kebersihan kandang dan tempat penampung susu memiliki nilai $x^{2}=0,53 ; \quad O R=3 ; \quad R R=1,5$. Kebersihan kandang dan tempat penampung susu memiliki kekuatan 3 kali berpengaruh terhadap jumlah $S$. aureus dalam susu kambing. Kebersihan kandang dan tempat penampung susu memiliki nilai OR lebih dari 1 , sehingga keduanya termasuk faktor risiko.

\section{Faktor Risiko Jumlah Koliform}

Jumlah koliform dalam susu kambing dari 16 peternakan di Kabupaten Sleman yang memenuhi persyaratan SNI No 01-6366-2000 87\%, sedangkan yang melebihi persyaratan SNI No 01-6366-2000 13\% disajikan dalam Tabel 1 . Jumlah koliform yang melebihi persyaratan SNI No 01-6366-2000 berasal dari peternakan I dan L. Pada peternakan I dan L saat pemerahan ambing tidak dicuci, sedangkan ambing yang tidak dicuci dapat sebagai sumber kontaminan bakteri dalam susu. Jumlah koliform dalam susu kambing dipengaruhi mulai pemerahan sampai tempat penyimpanan. Mencuci ambing sebelum pemerahan penting untuk dilakukan, karena ambing yang kotor oleh urin atau kotoran terjadi saat kambing rebahan di kandang. Peternakan kambing di Kabupaten Sleman yang mencuci ambing sebelum diperah $25 \%$, sedangkan yang tidak $75 \%$ disajikan. Selain mencuci ambing, tempat penyimpanan susu dapat mempengaruhi jumlah koliform. Susu yang disimpan pada suhu kamar jumlah koliform akan meningkat lebih cepat, sehingga menyimpan susu sebaiknya di refrigerator. Jumlah koliform dalam susu juga dipengaruhi oleh musim. Musim panas mendukung koliform untuk lebih cepat tumbuh dan berkembang (Berry dkk., 2006). Sementara itu Elmoslemeny dkk. (2009) menyatakan bahwa saat musim panas total bakteri akan lebih tinggi.

Mencuci ambing sebelum diperah memiliki korelasi dengan jumlah koliform (Tabel 5). Mencuci ambing sebelum diperah memiliki kekuatan 2 kali berpengaruh terhadap jumlah koliform dalam susu kambing, sehingga mencuci ambing sebelum diperah termasuk faktor risiko.
Tabel 5. Analisis faktor risiko jumlah koliform dalam susu kambing dari Kabupaten Sleman

\begin{tabular}{lccc}
\hline Variabel & $\left(\mathrm{X}^{2}\right)$ & $\begin{array}{c}\text { Odds } \\
\text { ratio (OR) }\end{array}$ & $\begin{array}{c}\text { Relative } \\
\text { risk (RR) }\end{array}$ \\
\hline $\begin{array}{l}\text { Mencuci ambing sebelum } \\
\text { diperah }\end{array}$ & 0,18 & $2^{*}$ & $1,3^{*}$ \\
Kebersihan kandang & 0,53 & $3^{*}$ & $2^{*}$ \\
Pemerah susu & 0,04 & $1,3^{*}$ & $1,2^{*}$ \\
Tempat penampung susu & 0,53 & $3^{*}$ & $2^{*}$ \\
Waktu pemerahan & 0,18 & 0,5 & 0,6 \\
Banyaknya pemerahan & 0,18 & 0,5 & 0,6 \\
\hline
\end{tabular}

Keterangan: * korelasi kuat terhadap koliform

Selain mencuci ambing sebelum diperah, kebersihan kandang dan tempat penampung susu juga memiliki korelasi yang kuat dengan jumlah. Kebersihan kandang dan tempat penampung susu memiliki kekuatan 3 kali berpengaruh terhadap jumlah koliform dalam susu kambing, sehingga kebersihan kandang dan tempat penampung susu termasuk faktor risiko.

\section{Faktor Risiko E. coli}

Salah satu kontaminan bakteri dalam susu kambing yang membahayakan kesehatan manusia adalah E. coli. Susu kambing dari 16 peternakan di Kabupaten Sleman $18 \%$ terkontaminasi $E$. coli, sedangkan $81 \%$ bebas $E$. Coli (Tabel 1). Kontaminasi E. coli pada susu kambing dapat terjadi karena kurangnya kebersihan mulai dari pemerahan sampai penyimpanan. Sumber $E$. coliantara lain kotoran dan urin kambing atau dari lingkungan sekitar kandang. Kebersihan kandang dan tempat penampung susu memiliki korelasi dengan kontaminan E. coli (Tabel 6).

Kebersihan kandang dan tempat penampung susu memiliki kekuatan 3 kali berpengaruh terhadap kontaminan $E$. coli. Oleh sebab itu kebersihan kandang dan tempat penampung susu termasuk faktor risiko kontaminan $E$. coli. Tempat penampung yang ditempatkan disekitar kandang dapat terkontaminasi $E$. coli, sehingga faktor penyimpanan tempat penampung susu berpengaruh terhadap kontaminan $E$. coli. Selain itu, sumber air yang digunakan untuk mencuci ambing dapat sebagai sumber kontaminan E. coli (Suwito dan Andriani, 2012). Hal tersebut terlihat pada susu yang terkontaminasi $E$. coli karena mencuci ambing dengan air sungai, sedangkan yang mencuci ambing dengan air sumur tidak terkontaminasi. Oleh sebab itu sumber air untuk mencuci ambing berperan dalam kontaminan $E$. coli pada susu.

Tabel 6. Analisis faktor risiko terhadap E. coli dalam susu kambing dari Kabupaten Sleman

\begin{tabular}{|c|c|c|c|}
\hline Variabel & $\left(x^{2}\right)$ & $\begin{array}{c}\text { Odds } \\
\text { ratio }(\mathrm{OR})\end{array}$ & $\begin{array}{l}\text { Relative } \\
\text { risk (RR) }\end{array}$ \\
\hline Kebersihan kandang & 0,53 & $3^{*}$ & $1,5^{*}$ \\
\hline Tempat penampung susu & 0,53 & $3^{*}$ & $1,5^{*}$ \\
\hline
\end{tabular}




\section{KESIMPULAN}

Faktor risiko yang mempengaruhi total bakteri, $S$. aureus, koliform, dan E. coli dalam susu kambing adalah kebersihan kandang, tempat penampung susu, pengetahuan personal hygiene pemerah susu, mencuci ambing sebelum diperah, waktu dan banyaknya pemerahan.

\section{UCAPAN TERIMA KASIH}

Ucapan terima kasih disampaikan kepada Badan Litbang Pertanian melalui KP3SL tahun 2015 yang telah memberikan dana penelitian sehingga penelitian ini dapat berlangsung. Terima kasih juga disampaikan kepada peternak kambing di Kabupaten Sleman dan Teknisi di Laboratorium Kesmavet FKH UGM atas kerjasama yang baik selama penelitian berlangsung.

\section{DAFTAR PUSTAKA}

Alarcon, B., Vicedo, B., \& Aznar, R. (2006). PCR based procedures for detection and quantification of Staphylococcus aureus and their application in food. Journal of Applied Microbiology, 100, 352-364. Doi: 10.1111/j.13652672.2005.02768.x

Albenzio, M., \& Santilo, A. (2011). Biochemical characteristics of ewe and goat milk: Effect on the quality of dairy products. Small Ruminant Research, 101, 33-40.

Agamy, E.I. (2007). The challenge of cow milk protein allergy. Small Ruminant Research, 68, 64-72. https://doi.org/10.1016/j.smallrumres.2006.09.016.

Barbano, D.M., Ma, Y., \& Santos, M.V. (2006). Influence of raw milk quality on fluid milk shelf life. Journal of Dairy Science, 89(E Supplement), 15-19. Doi: 10.3168/jds.S00220302(06)72360-8.

Barrow, G.I., \& Feltham, R.K.A. (1993). Cowan and Steel's Manual for the identification of Medical Bacteria. $3^{\text {th }}$ edition. Cambridge. Cambridge University Press.

Berry, D.P., O'Brien, B.E.J., O'Callaghan, Sullivan, K.O., \& Meanney, W.J. (2006). Temporal trends in bulk tank somatic cell count and total bacterial count in Irish dairy herds during the decade. Journal of Dairy Science, 89, 4083-4093. https://doi.org/10.3168/jds.S0022-0302(06)72453-5.

BSN (2000). Badan Standarisasi Nasional SNI 01-6366-2000 tentang batas maksimum cemaran mikroba dan batas maksimum residu dalam bahan makanan asal hewan.

BSN (2008). Badan Standarisasi Nasional SNI 01-2897-2008 tentang metode pengujian cemaran mikroba dalam daging, telur, dan susu serta hasil olahannya.

Ceballos, L.S., Morales, E.R., Adarve, G.D.L.T., Castro, J.D., Martinez, L.P., \& Sampelayo, M.R.S. (2009). Composition of goat and cow milk produced under similar conditions and analyzed by identical methodology. Journal of Food Composition and Analysis, 22, 322-329. https://doi.org/10.1016/j.jfca.2008.10.020.

Elmoslemany, A.M., Keefe, G.P., Dohoo, I.R., \& Dingwell. R.T. (2009). Microbiological quality of bulk tank raw milk in Prince Edwad Island dairy herds. Journal of Dairy Science, 92, 42394248. https://doi.org/10.3168/jds.2008-1751.

Eglezos, S., Huang, B., Gary, A., Dykes, Fegan, N., Bell, K., \& Stuttard. E. (2008). A survey of microbiological quality of frozen unpasteurised goats' milk in Queensland, Australia. The Australian Journal of Dairy Technology, 63, 79-81.
Marogna, G., Pilo, C., Vidili, A., Tola, S., Schianchi, G., \& Leori, S.G. (2012). Comparison of clinical findings, microbiological results, and farming parameters in goat herds affected by recurrent infectious mastitis. Small Ruminant Research, 102, 74-83. https://doi.org/10.1016/j.smallrumres.2011.08.013.

Park, Y.W., Juarez, M., Ramos, M., \& Haenlein, G.F.W. (2007). Physico chemical characteristics of goat and sheep milk. Small Ruminant Research, 68, 88-113. https://doi.org/10.1016/j.smallrumres.2006.09.013.

Ribeiro, A.C. 2010. Speciality products made from goat milk. Small Ruminant Research, 89, 225-233. https://doi.org/10.1016/j.smallrumres.2009.12.048.

SIDa (Sistem Informasi Daerah). (2013). Sistem informasi daerah kabupaten Sleman prioritaskan 4 komoditas unggulan. Badan Perencanaan Pembangunan Daerah Kabupaten Sleman.

Statistik Peternakan dan Kesehatan Hewan (2013). Direktorat Jenderal Peternakan dan Kesehatan Hewan. Kementrian Pertanian.

Suwito, W., \& Andriani. (2012). Teknologi penanganan susu yang baik dengan mencermati profil mikroba susu sapi di berbagai daerah. Jurnal Penelitian Pascapanen Pertanian, 9, http://dx.doi.org/10.21082/jpasca.v9n1.2012.35-44.

Suwito, W., Nugroho, S.W., Sumiarto, B., \& Wahyuni, A.E.T.H. (2014). Faktor-faktor risiko mastitis subklinis pada kambing peranakan Etawah di Kabupaten Sleman, Yogykarta. Jurnal Veteriner, 15, 130-138.

Taufik, E., Hildebrandt, G., Kleer, J.N., Wirjajanto, T.I., Kreausukon, K., Zessin, K.H., Baumann, M.P.O., \& Pasaribu, F.H. (2011). Microbiological quality of raw goat milk in Bogor Indonesia. Media Peternakan, 34, 105-111. Doi: 10.5398/medpet.2011.34.2.105.

Thrusfield (1995). Veterinary epidemiology, edisi $2^{\text {th }}$. Department of veterinary clinical studies. Royal (Dick) School of Veterinary Study. University of Edinburgh. Blackwell Science. 